\title{
Growth Consequences of Terrorism in Western Europe
}

\author{
Khusrav Gaibulloev and Todd Sandler*
}

\section{INTRODUCTION}

The unprecedented terrorist attack on the World Trade Center and the US Pentagon on September 11, 2001 (henceforth, 9/11) made the world acutely aware that transnational terrorist incidents can have a huge impact on gross domestic product (GDP). The direct and indirect cost of 9/11 on US GDP is put at $\$ 80-90$ billion (Kunreuther, Michel-Kerjan, and Porter 2003). Innovative work by Frey, Luechinger, and Stutzer (2004), based on a life-satisfaction approach, shows that self-reported losses of individuals from terrorism can be far greater than these economic consequences in terrorism-ridden countries.

Terrorism has the potential to curb economic growth through a number of channels. By increasing uncertainty, terrorism can reduce foreign direct investment (FDI) as investors seek less violence-prone countries (Abadie and Gardeazabal 2008, Enders and Sandler 1996, 2006). Moreover, terrorism can shift funds from growth-enhancing investment to less growth-promoting government spending on defensive counterterrorism measures. Terrorist attacks increase the cost of doing business (e.g., insurance premiums and higher salaries), which may limit investments. Terrorism can also lower growth by impacting key sectors, such as transportation, tourism, and trade. Finally, terrorism can adversely disrupt financial markets, thereby decreasing investment flows (Abadie and Gardeazabal 2003).

Our paper has a number of purposes. First, we present panel estimates for 18 Western European countries to ascertain the separate impacts of domestic and transnational terrorism on income per capita growth for 1971-2004. We focus

\footnotetext{
*Mr. Gaibulloev is a PhD candidate, School of Economic, Political \& Policy Sciences, University of Texas at Dallas, Richardson, TX 75080-3021, USA. Email: kng031000@utdallas.edu. Professor Sandler is the Vibhooti Shukla Professor of Economics and Political Economy at the University of Texas at Dallas. Email: tsandler@utdallas.edu. The authors are grateful to two anonymous referees for helpful comments. This research was partially supported by the United States Department of Homeland Security through the Center for Risk and Economic Analysis of Terrorism Events (CREATE) at the University of Southern California, grant number N00014-05-0630. However, any opinions, findings, and conclusions or recommendations are solely those of the authors and do not necessarily reflect the view of the Department of Homeland Security.
} 
on these 18 countries because we are able to construct a terrorist event data set that has both domestic and transnational terrorist attacks. Previous studies on the impact of terrorism on growth investigate either a single terrorism-ridden country (Abadie and Gardeazabal 2003) or else quantify just the transnational terrorism impact on a sample of countries (Blomberg, Hess, and Orphanides 2004). Because transnational terrorism may present different risks than domestic terrorism, there is no reason that the coefficient on transnational terrorism will necessarily reflect the true growth consequences in countries plagued with both domestic and transnational terrorist attacks. Second, we trace the fall in income per capita growth to reduced investment shares and augmented government spending shares that stem from terrorism. Third, through a series of tests, we distinguish the best empirical model from a host of competing specifications. Fourth, we perform numerous sensitivity tests to show that different model specifications have little effect on the empirical results. Finally, we draw policy conclusions.

We find that transnational terrorism has a greater negative marginal influence on income per capita growth than domestic terrorism. Each additional transnational terrorist incident per million persons reduces economic growth by about 0.4 percentage points. When both types of terrorist attacks are aggregated into a single measure, the resulting marginal impact is less than that associated with transnational terrorism. As anticipated, terrorist incidents reduce investment shares but increase government expenditure shares. When alternative forms of terrorism are distinguished, domestic terrorism is a more significant determinant of crowding-out of investment and crowding-in of government spending. At the margin, both types of terrorism have similar impacts on investment and government spending shares.

\section{METHODOLOGY}

Three key variables influence income per capita growth (growth). The initial level of income per capita $(y)$ is an essential determinant of economic growth, based on the notion of convergence in which the growth rate of a poorer country outpaces that of a richer country owing to diminishing returns in production (Barro 1991, Barro and Sala-i-Martin 1992). Convergence assumes that two comparison countries possess identical production functions and transition equations, but have different initial values of income per capita. The latter assumption is especially applicable to Western European countries that confront similar production conditions. A second essential influence on income per capita growth is the share of GDP devoted to investment $(I / G D P)$ (henceforth, known as the investment share). Higher shares provide the capital accumulation needed for economic growth. The third determinant of growth is 
the degree of trade openness (open), as measured by the ratio of the sum of exports and imports to GDP. More open economies are anticipated to grow faster in terms of income per capita as exports increase aggregate demand and imports may provide the necessary raw materials and, in some cases, technology transfers. Economic growth may also be negatively impacted by political violence and instability. For Western Europe, this instability is primarily in the form of domestic and transnational terrorism. The influences on growth is captured in equation (2), presented shortly.

\section{Empirical Specification}

In general, we consider the following empirical specification:

$$
q_{i t}=X_{i t} \beta+\alpha_{i}+\lambda_{t}+v_{i t}, \quad i=1, \ldots, N ; \quad t=1, \ldots, T .
$$

Equation (1) is a standard two-way error-component regression model (Baltagi 2005) where $q_{i t}$ denotes the dependent variable, $X_{i t}$ is a vector of explanatory variables of dimension $1 \times K$, and $\beta$ is a vector of parameters of dimension of $K \times 1$. The $i$ subscript identifies the country, while the $t$ subscript represents the time period. In (1), $\alpha_{i}$ and $\lambda_{t}$ represent the unobservable country-specific and time-specific effects, respectively, and $v_{i t}$ indicates the remaining disturbance.

To account for the impact of terrorism on growth, investment, and government spending shares, similar to Blomberg, Hess, and Orphanides (2004), we have the following three models to estimate:

$$
\begin{aligned}
\text { growth }_{i t}= & \beta_{0}+\beta_{1} \ln y_{i t-1}+\beta_{2} \ln (\text { open })_{i t}+\beta_{3}(I / \text { GDP })_{i t}+\beta_{4} \text { Terror }_{i t} \\
& +\alpha_{i}+\lambda_{t}+v_{i t}, \\
(I / G D P)_{i t}= & \gamma_{0}+\gamma_{1} \ln y_{i t-1}+\gamma_{2} \ln (\text { open })_{i t}+\gamma_{3} \text { Terror }_{i t}+\mu_{i}+\eta_{t}+\varepsilon_{i t},
\end{aligned}
$$

The terrorism variable (Terror) can be domestic terrorism, transnational terrorism, or both. In (3)-(4), the $\gamma \mathrm{s}$ and $\varphi s$ are parameters for estimation, whereas the remaining Greek symbols are error components. Equation (3) investigates the determinants of the investment share, while equation (4) examines the influences on government spending shares $(G / G D P)$. These equations relate investment and government shares, respectively, to standard growth influences and terrorism. In so doing, the estimates of these equations 
isolate terrorism's role in crowding out investment and crowding in government spending, thereby ascertaining and quantifying the path by which terrorism affects growth.

Our empirical strategy is as follows. We first perform several tests for the presence of unobservable effects - country-specific and time-specific effects. If there is evidence for unobservable effects, then we further investigate whether the effects are correlated with the regressors or not. Based on the test results, we then choose the appropriate specification and estimator for our models.

We consider three estimators: ordinary least squares $(O L S)$, Within (fixed effects), and generalized least squares ( $G L S$ ) (random effects). When unobservable effects are absent, the $O L S$ estimator is consistent and efficient. In the presence of unobservable effects, the $O L S$ estimator is still consistent, provided that the effects are uncorrelated with the explanatory variables; however, $O L S$ is less efficient than the $G L S$ estimator, because $O L S$ fails to account for the correlation of the disturbances within countries (time periods). The $G L S$ estimator is at least as efficient as the Within estimator insofar as the latter disregards the between variation. Endogeneity problems arise when the country-specific and/or time-specific components of the error term are correlated with the independent variables, so that both the $O L S$ and the $G L S$ estimators produce inconsistent results. The Within estimator, however, remains consistent. If unobservable effects are absent, we then apply $O L S$. If, however, unobservable effects are present but endogeneity is not an issue, we resort to GLS estimation. When unobservable effects are present and correlated with the regressors, we present Within estimations of the models. Finally, we perform a host of sensitivity tests to support our findings.

\section{Data}

Our data are drawn from three sources: Penn World Table Version 6.2 (Heston, Summers, and Aten 2006), International Terrorism: Attributes of Terrorist Events (ITERATE) (Mickolus et al. 2006), and Terrorism in Western Europe: Events Data (TWEED) (Engene 2007). We collected information for 18 countries of Western Europe and constructed a balanced panel data for the period of 1971 through $2004 .{ }^{1}$ We focus on these 18 European countries, because TWEED provides data on terrorist incidents, which can be merged with ITERATE data to yield event data on both domestic and transnational terrorist incidents. Such a comprehensive data set had not heretofore been

1. Sample countries are Austria, Belgium, Denmark, Finland, France, (West) Germany, Greece, Iceland, Ireland, Italy, Luxembourg, the Netherlands, Norway, Portugal, Spain, Sweden, Switzerland, and the United Kingdom. Prior to 1991, events are attributed to West Germany; after 1991 and unification, events are attributed to Germany. 
available for an important regional cohort of nations for an extended time period. Our analysis can, thus, quantify the macroeconomic consequences of terrorism for a set of developed economies that suffered both domestic terrorism and spillover transnational terrorism from the Middle East and elsewhere.

Annual growth of real GDP per capita, investment share of real GDP, and government expenditure share of real GDP are obtained from the Penn World Table data. Using this dataset, we also compute the log of lagged real GDP per capita $\left(\ln y_{i t-1}\right)$, and the $\log$ of the index of a country's openness at time $t$ $\left[\ln (\text { open })_{i t}\right]$. ITERATE, TWEED, and the Penn World Table are used to construct three measures of terrorism. The number of transnational terrorist incidents per million persons (trans_terror ${ }_{i t}$ ) is created to control for transnational terrorism effects, whereas the number of domestic terrorist events per million persons (dom_terror ${ }_{i t}$ ) is created to account for the effects of homegrown terrorism. The third terrorism measure is the number of all terrorist incidents per million persons (all_terror ${ }_{i t}$ ), which sums the first two terrorism variables. In total, the resulting panel dataset covers 18 Western European countries for 34 years for 612 observations.

ITERATE records key information about transnational terrorist events such as its date, country location, incident type, and casualty figures (Enders and Sandler 2006, pp. 55-60). TWEED records internal terrorist events within 18 Western European countries. A terrorist act is internal when the terrorists operate within their own country. If the terrorists cross into Europe from abroad, then TWEED excludes any subsequent terrorist acts by these terrorists (Engene 2007). If, however, a French terrorist assassinates an American, TWEED would include the attack, since its notion of internal terrorism is geared solely to the nationality of the terrorist group and not that of the victim. Thus, some terrorist events in ITERATE may also be in TWEED, because ITERATE considers both the nationality of perpetrators and victims when classifying transnational terrorism. The French example would be recorded in ITERATE, because the victim was of a different nationality than the perpetrator. TWEED's internal terrorism is generally domestic, but not always. TWEED relies on the Keesing's Record of World Events (Keesing's Contemporary Archives) and covers terrorist events from 1950 through 2004.

Merging the ITERATE and TWEED datasets posed many challenges. ${ }^{2}$ To come up with a common time period, we settled on 1971-2004. We excluded 1968-70 because the Penn World Tables has some missing macroeconomic data prior to 1971 and we wanted a balanced panel. A second difficulty

2. How we surmounted these challenges are discussed in detail in an Appendix, available from the authors upon request. 
concerns TWEED's reporting actions initiated by governments as 'events.' To rectify this problem, we dropped all incidents that are coded 2 (state institution) or 3 (missing data) in Variable 5 (Type of Agent) of TWEED (Engene 2006). Next, we had to come up with a common country code for TWEED and ITERATE, so that we can compare incidents to remove duplicates. We applied TWEED's country codes to ITERATE and treated Northern Ireland in ITERATE as the United Kingdom to correspond to TWEED's treatment. To match potential duplicate incidents, we also had to recognize that TWEED classified only 10 kinds of terrorist events, while ITERATE distinguished 25 types of terrorist events. Part of this difference comes from ITERATE's practice of distinguishing specific types of bombings and hostage-taking events. When we could not match incident type for potential duplicate events, we referred to other identifying variables such as date, country, and casualty figures.

By examining key variables, we were able in most cases to identify duplicate events. The biggest challenge was posed by country location, since ITERATE recorded both a start and end country location, while TWEED only recorded a venue location. Potential problems arose when start and end locations were not the same, which was mostly the case for some skyjackings and letter bombings. In essence, we had to rely on the incident write-up in ITERATE to assign the incident to the proper country where the incident took place. For example, a letter bomb mailed from London to Paris, where it exploded, was assigned to France as the venue country. Matching events between ITERATE and TWEED was especially difficult when either the month or day was missing, which was a more common problem for TWEED (3064 observations) than for ITERATE (275 events). Of the TWEED observations with missing dates, 1565 incidents also had missing incident type. These latter events had to be discarded. Painstaking effort went into trying to match the remaining events with missing dates, based on ITERATE write-ups and known variables. We found 536 duplicate events, which, with few exceptions, were classified as transnational terrorism. In the end, the merged data set includes 3507 transnational terrorist events and 6475 domestic terrorist events. The terrorist observations in the merged dataset are recorded daily for each country, while the Penn World Table reports population and macroeconomic variable on a yearly basis for each country. Therefore, we transformed our terrorism event data into a country-year format. Based on population from the Penn World Table, we computed the number of terrorist (domestic, transnational, and all) events per million persons.

Figure 1 displays the number of terrorist events per year for our sample period. Total terrorist events are shown, along with domestic and transnational terrorist events. In Figure 1, domestic terrorism indicates more variability than transnational terrorism, with domestic terrorism being the dominant influence 
Figure 1

Terrorist events in Western Europe, 1971-2004

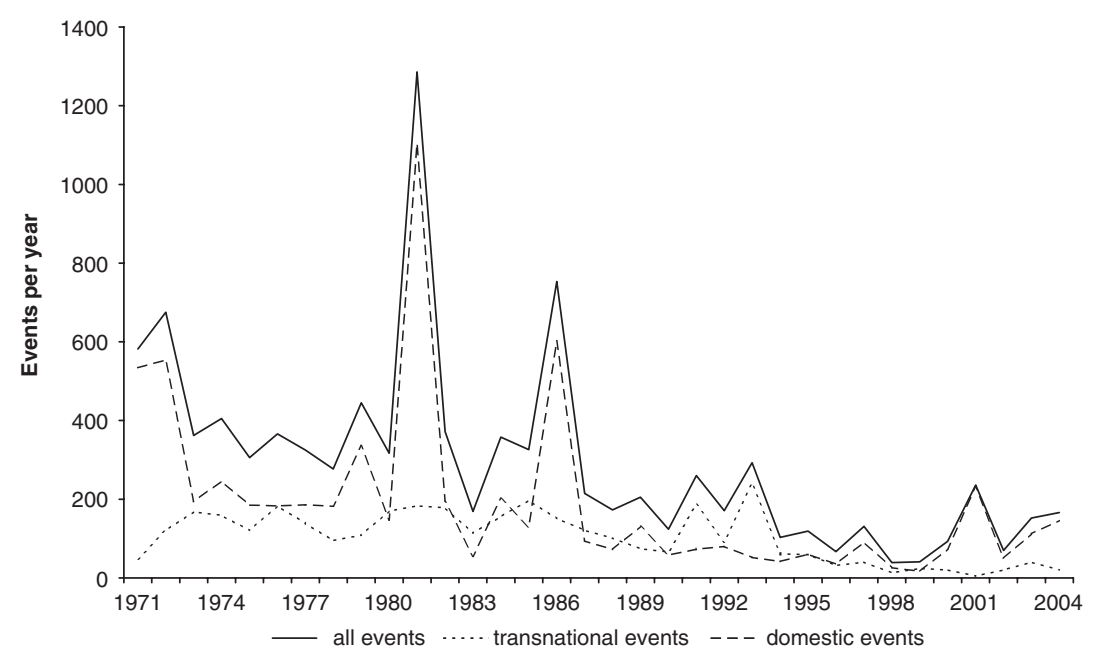

in the late 1970s and throughout much of the 1980s. Since 1999, domestic terrorism is again the primary influence in Western Europe. In contrast, transnational terrorism was the main influence in the early 1990s. The graph also shows that terrorism is much reduced since the late 1980s due, in large part, to successful proactive countermeasures against leftist domestic terrorists.

During the sample period, the six most terrorism-ridden countries are as follows: the United Kingdom, 3842 incidents; France, 2271 incidents; Spain, 949 incidents, (West) Germany, 794 incidents; Italy, 647 incidents; and Greece, 555 incidents. The United Kingdom ranked first on both domestic and transnational terrorism owing to the 'Irish troubles.' (West) Germany ranked second on transnational terrorism, while France ranked second on domestic terrorism. When normalized by population, the top six terrorism-plagued countries are in decreasing order as follows: the United Kingdom, Greece, France, Ireland, Portugal, and Spain.

\section{RESULTS}

Although not presented here, we investigated the long-run effect of the terrorism variables on growth, but obtained statistically insignificant results, ${ }^{3}$

3. A table of results is available upon request. 


\section{KHUSRAV GAIBULLOEV/TODD SANDLER}

\section{Table 1}

Two-Way Random-Effects Estimation of the Growth Model

\begin{tabular}{|c|c|c|c|c|c|}
\hline Variable & Model 1 & Model 2 & Model 3 & Model 4 & Model 5 \\
\hline $\ln y_{i t-1}$ & $\begin{array}{c}-2.944^{* * *} \\
(0.606)\end{array}$ & $\begin{array}{c}-3.018^{* * *} \\
(0.593)\end{array}$ & $\begin{array}{c}-2.870^{* * *} \\
(0.606)\end{array}$ & $\begin{array}{c}-3.030^{* * *} \\
(0.600)\end{array}$ & $\begin{array}{c}-2.465^{* * *} \\
(0.530)\end{array}$ \\
\hline $\ln (\text { open })_{i t}$ & $\begin{array}{l}1.450^{* * *} \\
(0.345)\end{array}$ & $\begin{array}{l}1.464^{* * *} \\
(0.331)\end{array}$ & $\begin{array}{l}1.476^{* * *} \\
(0.345)\end{array}$ & $\begin{array}{l}1.445^{* * *} \\
(0.338)\end{array}$ & $\begin{array}{l}1.244^{* * *} \\
(0.282)\end{array}$ \\
\hline$(I / G D P)_{i t}$ & $\begin{array}{l}0.202^{* * *} \\
(0.030)\end{array}$ & $\begin{array}{l}0.205^{* * *} \\
(0.030)\end{array}$ & $\begin{array}{l}0.208^{* * *} \\
(0.030)\end{array}$ & $\begin{array}{l}0.201^{* * *} \\
(0.030)\end{array}$ & \\
\hline all_terror $_{i t}$ & $\begin{array}{c}-0.153^{* *} \\
(0.072)\end{array}$ & & & & \\
\hline trans_terror $r_{i t}$ & & $\begin{array}{c}-0.374^{* *} \\
(0.158)\end{array}$ & & $\begin{array}{c}-0.372^{* *} \\
(0.158)\end{array}$ & $\begin{array}{c}-0.446^{* * *} \\
(0.161)\end{array}$ \\
\hline dom_terror $_{i t}$ & & & $\begin{array}{r}-0.095 \\
(0.082)\end{array}$ & $\begin{array}{c}-0.093 \\
(0.081)\end{array}$ & $\begin{array}{c}-0.171^{* *} \\
(0.082)\end{array}$ \\
\hline Constant & $\begin{array}{l}20.629^{* * *} \\
(5.458)\end{array}$ & $\begin{array}{l}21.270^{* * * *} \\
(5.337)\end{array}$ & $\begin{array}{l}19.612^{* * *} \\
(5.433)\end{array}$ & $\begin{array}{l}21.586^{* * *} \\
(5.407)\end{array}$ & $\begin{array}{l}21.569^{* * *} \\
(4.809)\end{array}$ \\
\hline Sample size & 612 & 612 & 612 & 612 & 612 \\
\hline Hausman (df) & $6.820(4)$ & $6.379(4)$ & $8.542(4)$ & $8.466(5)$ & $5.439(4)$ \\
\hline p-value & 0.146 & 0.173 & 0.074 & 0.132 & 0.245 \\
\hline
\end{tabular}

Notes: Hausman test is between two-way fixed effects and two-way random effects (IMLE). $\mathrm{df}$ denotes the degree of freedom and $\mathrm{p}$-value is the probability value. We also performed Wald test of the augmented regression and obtained similar results. Standard errors are in parentheses. Significance levels: ${ }^{* * *}$ is $.01,{ }^{* *}$ is .05 , and ${ }^{*}$ is .10 .

which is not surprising given our small sample size. In particular, we applied the Between estimator to regress income per capita growth as a function of the log of initial GDP (i.e., GDP in 1970), investment share, and the terrorism measure(s).

We, therefore, turn to the panel country-year estimates, based on the growth regression in (2), previously presented. We investigate a number of specification tests that include Breusch-Pagan Lagrange multiplier (LM) test, Honda's and King and Wu's one-sided LM tests, F-test, likelihood ratio test, and Baltagi's conditional LM tests (Baltagi 2005, Chapter 4). We test for the presence of individual-specific effects, time-specific effects, and joint individual-specific and time-specific effects. We also test the null hypothesis of no individual-specific effects, conditional on the positive time-specific effects, as well as no time-specific effects, conditional on the presence of individualspecific effects. All specification tests (available on request) strongly indicate that there are both individual- and time-specific effects, so that we specify our growth equation as a two-way error-component model. The Hausman test between two-way fixed effects and two-way random effects fails to reject the hypothesis of no correlation between the unobserved effects and the regressors (Table 1). Thus, based on efficiency grounds, we choose the twoway random-effects estimator over the corresponding fixed-effects estimator. 
More specifically, we implement the random-effects estimator using Breusch's iterative maximum likelihood estimation approach (IMLE). ${ }^{4}$

Estimation results are given in Table 1. Models 1 through 3 sequentially use three measures of terrorism: namely, the aggregate number of terrorist incidents per million persons; the number of transnational terrorist events per million persons; and the number of domestic terrorist incidents per million persons, respectively. Model 4 includes both transnational and domestic terrorist incidents as separate regressors. Model 5 excludes the investment share from Model 4 to address a positive multicollinearity issue raised below. The signs and significance of the standard growth determinants agree with the growth literature. In particular, the lagged value of GDP per capita, which captures convergence, has the anticipated negative effect on growth. Economic openness and the investment share are conducive to economic growth. These results are robust and statistically significant across all five models.

The terrorism measures have the predicted negative impact on growth; different measures of terrorism have dissimilar effects in terms of magnitude and significance. The coefficient of aggregate terrorist incidents is about -0.15 , indicating that on average an additional terrorist incident per million persons decreases income per capita growth by about 0.2 of a percentage point. This effect is statistically significant at the .05 level. A similar one incident increase in transnational terrorist events per million persons is associated with a decline in growth of about 0.4 percentage points. The coefficient on the domestic terrorism variable is relatively small, but is not statistically significant. When we include both domestic and transnational terrorism in the same model (Model 4), the results do not change. That is, both variables have negative coefficients, with just the transnational terrorism coefficient being statistically significant. Moreover, the magnitude of the terrorism coefficients in Model 4 is almost identical to the corresponding coefficients in Model 2 and 3. In summary, transnational terrorism has a much stronger effect on growth than domestic terrorism. This suggests that economies are more susceptible to outside than to inside terrorist threats. The former may also scare away FDI (Abadie and Gardeazabal 2008).

One potential cause for the insignificant effect of domestic terrorism may be its relatively strong correlation of -0.19 with the investment share. This contrasts with the correlation between the investment share and transnational terrorist events, which is only -0.07 . When, in Model 5, the investment share is excluded, the domestic terrorism coefficient becomes statistically significant,

4. Hausman's test is weakly significant at the .10 level for Model 3 in Table 1; however, the fixed-effects estimator gives virtually the same estimates as random effects. This is later shown in our sensitivity analysis. 


\section{KHUSRAV GAIBULLOEV/TODD SANDLER}

\section{Table 2}

Sensitivity of Terrorism Estimates to Various Estimators of the Growth Regression

\begin{tabular}{lccccc}
\hline Variable & IMLE & Swamy \& Arora & Wallace \& Hussain & Amemiya & Fixed Effects \\
\hline all_terror $_{i t}{ }^{\mathrm{a}}$ & $-0.153^{* *}$ & $-0.147^{* *}$ & $-0.152^{* *}$ & $-0.155^{* *}$ & $-0.159^{* *}$ \\
& $(0.072)$ & $(0.073)$ & $(0.072)$ & $(0.073)$ & $(0.074)$ \\
trans_terror $_{i t} \mathrm{~b}^{\mathrm{b}}$ & $-0.372^{* *}$ & $-0.384^{* *}$ & $-0.371^{* *}$ & $-0.372^{* *}$ & $-0.318^{*}$ \\
& $(0.158)$ & $(0.159)$ & $(0.158)$ & $(0.159)$ & $(0.165)$ \\
dom_terror $_{i t}{ }^{\mathrm{b}}$ & -0.093 & -0.083 & -0.093 & -0.094 & -0.119 \\
& $(0.081)$ & $(0.082)$ & $(0.081)$ & $(0.082)$ & $(0.083)$ \\
Sample size & 612 & 612 & 612 & 612 & 612 \\
\hline
\end{tabular}

Notes: ${ }^{\mathrm{a}}$ Model 1 of Table 1 is estimated. ${ }^{\mathrm{b}}$ Model 4 of Table 1 is estimated.

Estimates of all regressors other than terrorism variables are suppressed (see Model 1 and Model 4 of Table 1 for specification). Standard errors are in parentheses.

Significance levels: ${ }^{* * *}$ is $.01,{ }^{* *}$ is .05 , and ${ }^{*}$ is .10 .

while the significance of the transnational terrorism coefficient increases. Furthermore, the magnitude of both coefficients gets larger in absolute terms. The last result is not surprising because omitting the investment variable introduces a downward bias to these parameters.

As a sensitivity analysis, we implement a number of random-effects and fixed-effects estimators for our growth model. The resulting estimates are similar in terms of signs and significance to the findings in Table 1; however, there are some discrepancies regarding the size of the coefficients across models. These differences merit discussion because we are not only interested in the statistical significance of the terrorism variables, but also in the magnitude of their coefficients. Table 2 displays the estimation results of Model 1 and Model 4 of Table 1, using five estimators - four two-way random-effects estimators (IMLE, Swamy and Arora, Wallace and Hussain, and Amemiya) and a twoway fixed-effects estimator (see, e.g., Baltagi, 2005). To conserve space, we only present the estimates of the terrorism variables. In Table 2, the sign and statistical significance of the various terrorism coefficients remain robust across the estimators. For the five estimators, the aggregate terrorism coefficients range between -0.147 and -0.159 ; the transnational terrorism coefficients vary between -0.318 and -0.384 ; and the insignificant domestic terrorism coefficients are between -0.083 and -0.119 .

Thus far, our findings do not identify the channel through which a country's economic growth is adversely influenced by domestic and transnational terrorist attacks. A likely channel is through crowding out growth-enhancing investment for less growth-promoting increases in government spending in the form of defensive and proactive counterterrorism measures. To examine this hypothesis, we estimate the effect of terrorism on investment and government spending shares of GDP - see equations (3) and (4). The crowding-out/ crowding-in hypothesis is consistent with the terrorism variables having a 


\section{Table 3}

Two-Way Fixed-Effects Estimation of Investment and Government Expenditure Models

\begin{tabular}{|c|c|c|c|c|}
\hline \multirow[t]{2}{*}{ Variable } & \multicolumn{2}{|c|}{ investment share } & \multicolumn{2}{|c|}{ government spending share } \\
\hline & Model 1 & Model 2 & Model 1 & Model 2 \\
\hline $\ln y_{i t-1}$ & $\begin{array}{l}5.471^{* * * *} \\
(1.281)\end{array}$ & $\begin{array}{l}5.471^{* * * *} \\
(1.284)\end{array}$ & $\begin{array}{c}-4.607^{* * *} \\
(0.774)\end{array}$ & $\begin{array}{c}-4.600^{* * *} \\
(0.776)\end{array}$ \\
\hline $\ln (\text { open })_{i t}$ & $\begin{array}{l}3.122^{* * *} \\
(0.974)\end{array}$ & $\begin{array}{l}3.121^{* * * *} \\
(0.981)\end{array}$ & $\begin{array}{c}-1.379^{* *} \\
(0.588)\end{array}$ & $\begin{array}{c}-1.366^{* *} \\
(0.593)\end{array}$ \\
\hline all_terror $_{i t}$ & $\begin{array}{c}-0.335^{* * *} \\
(0.087)\end{array}$ & & $\begin{array}{l}0.174^{* * *} \\
(0.053)\end{array}$ & \\
\hline trans_terror $_{i t}$ & & $\begin{array}{r}-0.337^{*} \\
(0.197)\end{array}$ & & $\begin{array}{c}0.194 \\
(0.119)\end{array}$ \\
\hline dom_terror $_{i t}$ & & $\begin{array}{c}-0.335^{* * *} \\
(0.098)\end{array}$ & & $\begin{array}{l}0.169^{* * * *} \\
(0.059)\end{array}$ \\
\hline Sample size & 612 & 612 & 612 & 612 \\
\hline Wald (df) & $27.419(3)$ & $27.759(4)$ & $36.060(3)$ & $37.991(4)$ \\
\hline p-value & 0.000 & 0.000 & 0.000 & 0.000 \\
\hline
\end{tabular}

Notes: Constant, time, and individual dummies are suppressed. Wald test from augmented regression is asymptotically equivalent to Hausman test between two-way fixed effects and two-way random effects (IMLE) (see e.g., Baltagi 2005). df is the degree of freedom and p-value denotes the probability value. We do not report the Hausman statistics because the matrix of the difference between variances of the fixed-effects estimates and the random-effects estimates was not positive definite. Standard errors are in parentheses.

Significance levels: $* * *$ is $.01, * *$ is .05 , and $*$ is .10 .

negative influence on the investment share and a positive impact on the government spending share.

Before estimating (3)-(4), we performed specification tests analogous to those for the growth model and found support for the two-way errorcomponent specification. The Wald test for augmented regressions (an equivalent to the Hausman test) suggests that there is correlation between unobserved effects and the explanatory variables. To avoid this endogeneity concern, we employ the two-way fixed-effects estimator. For aggregate terrorist events, Table 3 shows that an additional incident per million persons reduces investment share in GDP by a third of a percentage point, but augments the government spending share by about half that amount. When we decompose the terrorist incidents into transnational and domestic events per million persons, we find that both result in an investment decline, but transnational terrorism is only weakly significant. The coefficients of transnational terrorism, domestic terrorism, and aggregate terrorism are nearly the same in terms of their influence on crowding-out of investment. Evidence from the government spending regression suggests that domestic terrorism also leads to higher government spending: an additional domestic incident per million persons causes the government spending share to rise by less than 0.2 
percentage points. The coefficient for transnational terrorist events is also positive at a value just under 0.2 , but is not statistically significant. ${ }^{5}$

When we disaggregate terrorism into its domestic and transnational components, we find that the aggregate number of terrorist events does not tell the whole story. There is a marked difference between transnational and domestic terrorism in terms of their impacts on growth, with transnational terrorism having the larger influence. At first sight, it appears that domestic terrorism does not affect economic growth. However, an investigation of GDP components reveals the opposite: domestic terrorism crowds out investment spending and crowds in government spending, with crowding-out being almost twice as large as crowding-in. When the investment variable is excluded from the growth regression, domestic terrorism becomes a significant negative determinant of economic growth.

\section{CONCLUDING REMARKS}

Both transnational and domestic terrorism adversely affected income per capita growth in Western Europe during 1971-2004. The negative growth effects results, in part, from terrorism reducing growth-enhancing investment and increasing more growth-neutral government spending. In the case of transnational terrorism, an additional incident per million people reduces economic growth by about 0.4 percentage points. At first sight, this seems like a huge effect since most countries grow on average by just 2 percent. To provide a better perspective on this magnitude, consider France with a population of 60 million people. Transnational terrorism would have to increase by a full 60 incidents for growth to drop by about 0.4 percentage points. If, say, there are ten more terrorist attacks, then income per capita growth would fall by about 0.06 percentage points. This is consistent with findings in past studies by Blomberg, Hess, and Orphanides (2004) and Tavares (2004) for different time periods and sample countries. The influence of domestic terrorism on economic growth is half of this effect. For Western Europe, these modest effects agree with recent studies that argue that mature economies are sufficiently diversified to withstand a moderate terrorist campaign without displaying large economic consequences (Enders and Sandler 2006).

Because of the crowding-out of investment and the augmentation of government spending on countermeasures, it is in a government's interest to eliminate, if possible, the terrorist threat. If a besieged government merely

5. If we estimate the government spending regression using random effects, then the terrorism variables, including transnational terrorism, become statistically significant at the .05 level. However, we cannot rely on these estimates owing to the endogeneity problem, identified by the Wald test. 
deploys defensive measures to limit terrorism damages and to shift terrorist attacks to less valuable targets, the economy is locked into a flow of counterterrorism spending that crowds out more productive investments. Proactive countermeasures to eliminate the terrorist threat will lead to less crowding-out in the long term. Europe succeeded by the late 1980s (see Figure 1) to reduce its domestic terrorism through effective proactive policies against the Red Brigades, Direct Action, the Communist Combatant Cells, the Red Army Faction, and others. These efforts would have had a significant economic payoff. Greater cooperation will be needed for these governments to succeed in their proactive policies against transnational terrorist attacks, because there is a strong incentive for countries to rely on defensive policies in the hopes of transferring transnational attacks abroad. This paper shows that such myopic action does not eliminate the adverse economic impacts on growth, stemming from the crowding-out of investment and the crowding-in of government spending. Since transnational terrorism has a larger impact on growth than domestic terrorism, West European efforts to curb transnational terrorism will have a greater economic dividend than efforts to limit domestic terrorism.

\section{REFERENCES}

Abadie, Alberto and Javier Gardeazabal (2003). The Economic Costs of Conflict: A Case Study of the Basque Country, American Economic Review. 93: 113-132.

Abadie, Alberto and Javier Gardeazabal (2008). Terrorism and the World Economy, European Economic Review. 52: 1-27.

Baltagi, Badi H. (2005). Econometric Analysis of Panel Data. $3^{\text {rd }}$ Ed. Chichester, UK: John Wiley \& Sons.

Barro, Robert J. (1991). Economic Growth in a Cross Section of Countries, Quarterly Journal of Economics. 106: 407-443.

Barro, Robert J. and Xavier Sala-i-Martin (1992). Convergence, Journal of Political Economy. 100: 223-251.

Blomberg, S. Brock, Gregory D. Hess and Athanasios Orphanides (2004). The Macroeconomic Consequences of Terrorism, Journal of Monetary Economics. 51: 1007-1032.

Enders, Walter and Todd Sandler (1996). Terrorism and Foreign Direct Investment in Spain and Greece, Kyklos. 49: 331-352.

Enders, Walter and Todd Sandler (2006). The Political Economy of Terrorism. Cambridge: Cambridge University Press.

Engene, Jan O. (2006). TWEED Code Book. Bergen, NO: Department of Comparative Politics, University of Bergen.

Engene, Jan O. (2007). Five Decades of Terrorism in Europe: The TWEED Dataset, Journal of Peace Research. 44: 109-121.

Frey, Bruno S., Simon Luechinger and Alois Stutzer (2004). Valuing Public Goods: The Life Satisfaction Approach. CESifo Working Paper No. 1158, CESifo, Munich.

Heston, Alan, Robert Summers and Bettina Aten (2006). Penn World Table Version 6.2. Philadelphia, PA: Center for International Comparisons of Production, Income and Prices, University of Pennsylvania. 


\section{KHUSRAV GAIBULLOEV/TODD SANDLER}

Kunreuther, Howard, Erwann Michel-Kerjan and Beverly Porter (2003). Assessing Managing and Financing Extreme Events: Dealing with Terrorism. Working Paper 10179, National Bureau of Economic Research, Cambridge, MA.

Mickolus, Edward F., Todd Sandler, Jean M. Murdock and Peter Flemming (2006). International Terrorism: Attributes of Terrorism Events, 1968-2005. Dunn Loring, VA: Vinyard Software.

Tavares, Jose (2004). The Open Society Assesses Its Enemies: Shocks, Disasters and Terrorist Attacks, Journal of Monetary Economics. 51: 1039-1070.

\section{SUMMARY}

This paper presents panel estimates for 18 Western Europe countries to ascertain the separate impacts of domestic and transnational terrorism on income per capita growth for 1971-2004. The paper merges domestic and transnational terrorist events in order to attribute growth impacts to the two broad categories of terrorism. Each additional transnational terrorist incident per million persons reduces economic growth by about 0.4 percentage points. Domestic terrorism has a much smaller effect on growth that is about half this size. Terrorism's negative impact on growth is related to the scale of terrorism in the sample countries in order to give a better idea of what is the average consequence in most sample countries. These negative impacts are shown to stem from domestic and transnational terrorism's adverse influence on investment shares. Counterterrorism efforts also augment government spending, which crowds out growth-promoting investment. We show that the pathway by which domestic and transnational terrorism influences growth differs. For example, transnational terrorism works more through the crowding out of investment, while domestic terrorism works more through the increase in government expenditure increases. A host of sensitivity tests are performed to support our empirical model. Policy recommendations conclude the paper - e.g., measures to curb transnational terrorist attacks have a higher economic payoff than similar measures to reduce domestic terrorist events. Since transnational terrorism has a larger impact on income per capita growth than does domestic terrorism, West European efforts to curb transnational terrorism will have a greater economic dividend than efforts to limit domestic terrorism. 